\title{
A study of Spanish sepiolite workers
}

\author{
K McConnochie, C Bevan, R G Newcombe, J P Lyons, ${ }^{\star}$ J W Skidmore, J C Wagner
}

Section of Respiratory Medicine, University of Wales College of Medicine, Llandough Hospital, Penarth, S Glamorgan, CF6 1XX K McConnochie C Bevan

Department of Medical Computing and Statistics, University of Wales College of Medicine, Cardiff CF4 4XW R G Newcombe

Cardiff and Swansea Pneumoconiosis Medical Panels, Cardiff CF1 4YT J P Lyons*

Cardiff CF3 7HW

$\mathrm{J}$ W Skidmore (dust physicist)

Medical Research

Council

Pneumoconiosis

Unitt, Cardiff

CF6 1XY

J C Wagner

${ }^{\star}$ Died 1991

†Disbanded 1985

Reprint requests to: Dr K McConnochie Received 8 June 1992 Returned to authors 17 July 1992

Revised version received 12 October 1992

Accepted 17 November 1992

\begin{abstract}
Background-Sepiolite is an absorbent clay that is used as pet litter. It forms thin crystals, which are a transition between chain and layered silicates. Inhalation studies in animals have shown no evidence of pulmonary damage. This paper reports a cross sectional study of the total work force of the largest sepiolite production plant in the world.
\end{abstract}

Methods-Two hundred and eighteen workers (210 men and eight women) were studied. Height, age, and smoking history were recorded. Chest radiographs were read according to the International Labour Office (ILO) classification by two readers. Readings were used to construct a numerical score, which was then used in statistical analyses. Forced expiratory volume in one second $\left(F V_{1}\right)$ and forced vital capacity (FVC) were divided by the square of the height. Casella size selective personal samplers were used in randomly selected operatives to collect dust eight years before the rest of the study was carried out. These samples were evaluated gravimetrically. Total dust samples were examined by optical and electron microscopes. Results were analysed by bivariate linear regression, $\chi^{2}$ tests, and analysis of variance.

Results-When allowance was made for smoking habit workers exposed to dry dust showed a significantly greater decline in $F E V_{1}$ with age than workers with little exposure to dry dust. A similar pattern applied to FVC. Radiographic score showed deterioration with age but no clear differences from other variables. High concentrations of dust were found in the bagging department and also in the classifier shed.

Conclusions-The major finding was that lung function deteriorated more rapidly in those who had had more exposure to dust, but there was no evidence of any accompanying radiographic change.

(Thorax 1993;48:370-374)

Sepiolite is a clay that represents a transition between a chain and a layered silicate. It may form thin, lath like crystals that have absorbent properties and therefore find a wide range of commercial applications. Sepiolite is a constituent of animal feeds, cigarette filters, pesticide carriers, drilling muds, and industrial catalysts but it finds most use as litter for domestic pets. Wagner et $a l^{1}$ investigated the biological effects of Spanish sepiolite inhalation in animals and found little evidence of carcinogenicity or potential for other pulmonary damage.

The effects of inhaling sepiolite in man are unknown. This paper reports a cross sectional study of the total work force of the largest sepiolite production plant in the world, which has been in operation for over 30 years. Our aim was to look for evidence of accelerated decline in lung function and radiological abnormality with prolonged inhalation of sepiolite.

\section{Methods}

THE PLANT

The plant we studied is situated in the outskirts of Madrid and owned by Tolsa SA. Workers in this plant handle sepiolite exclusively. The mineral is obtained from an open cast mine, stockpiled, and when required transferred by mechanical shovel to a primary crusher and then on to a conveyor belt for grinding, heat treatment, and size classification. The material is then bagged and distributed. Exposure to the dust may occur in the classifier shed, the storage and transport loading area, the loading point of the primary crusher, and the bagging department. In its natural state sepiolite contains about $42 \%$ moisture, and mine workers are thus exposed to very little respirable dust. After natural and artificial drying the commercial product contains about $12 \%$ moisture.

\section{SUBJECTS}

We studied the total current work force of 218 (210 men and eight women) Their occupations are shown in table 1 . For each worker exposure to other occupational dust was noted. Height, weight, age, and smoking history were recorded for each worker. Smoking habits were recorded by classifying the workers as never smokers, ex-smokers and current smokers.

\section{RADIOLOGY}

Each worker had a full size posteroanterior chest radiograph. Films were read, according to the International Labour Organisation (ILO) classification ${ }^{2}$ by two experienced readers. A numerical score was derived from these readings by the method of Oldham, ${ }^{3}$ which allows for continuous variation and hence use of the data for linear regression analyses. 
Table 1 Number of workers in each occupational group who had lung function tests

\begin{tabular}{lll}
\hline & \multicolumn{2}{l}{ Number } \\
\cline { 2 - 3 } & Total & $\begin{array}{l}\text { With lung } \\
\text { function data }\end{array}$ \\
Occupation & & \\
\hline PLANT wORKERS & 44 & 39 \\
Packaging & \\
Various others, including: & 76 & 74 \\
$\quad \begin{array}{l}\text { Production work } \\
\quad \text { Weighbridge work }\end{array}$ & & \\
$\quad$ Drying and sieving & & \\
$\quad$ Driving & \\
MAINTENANCE wORKERS & & \\
General, including: & 23 & 23 \\
$\quad$ Electrician & & \\
$\quad$ Warehouseman & & \\
$\quad$ Workshop & & \\
OFFICE WORKERS & 24 & 22 \\
LABORATORY wORKERS & 30 & 30 \\
MINE wORKERS & 21 & 20 \\
\hline
\end{tabular}

\section{LUNG FUNCTION TESTS}

Forced expiratory volume in one second $\left(F E V_{1}\right)$ and forced vital capacity (FVC) (BTPS) were obtained by calculating the mean of the two highest readings unless the blows differed by more than 0.3 litres, in which case the higher reading was used. We excluded some blows on account of poor technique, leaving 208 (95\%) subjects with usable results. $\mathrm{FEV}_{1}$ and FVC were divided by height ${ }^{2}$, as suggested by Cole. ${ }^{4}$

\section{DUST ANALYSIS}

The dust exposure of the plant operatives was assessed by measuring the airborne dust concentrations in the various departments. Casella size selective personal samplers were used for periods exceeding six hours. Operatives were randomly selected. Respirable dust samples obtained in their breathing zones were evaluated gravimetrically.

In addition, samples of total dust obtained over short periods were analysed by the optical and electron microscope to determine fibre concentrations numerically. These samples were analysed eight years before the lung function data were collected. We could not obtain contemporary data; anecdotal evidence, however, suggests that dust concentrations had fallen and therefore the earlier measurements may be more relevant to the exposure of the workers. To assess the potential for release of fibres under wet and disper- sive conditions, which to some extent may occur in the lung, samples of sepiolite of respirable size were wetted and subjected to gentle and vigorous dispersion. ${ }^{5}$

\section{STATISTICAL METHODS}

The only type of analysis possible with these data is internal comparison between groups of workers with different occupations. This is not entirely satisfactory because no normative data for the population are available and because the sample size is not large enough to reveal other than gross effects. The following techniques were used: bivariate linear regression analysis for gradient of lung function measurements with age within occupation and smoking groups, analysis of variance for effects of occupation, and $\chi^{2}$ tests for association of smoking habit with occupation.

\section{Results}

The distributions of age, smoking habits, and length of employment in each of the occupational groups are shown in table 2 . Of the eight women, four were in the office and four in the laboratory. There was nothing distinctive in the age, smoking habit, occupation, or radiographic appearances of the 10 workers for whom lung function data were not available. Agreement between the two radiograph readers was generally good (table 3 ). The readers agreed that the films of seven subjects showed pleural change, and five other films were considered to show similar change by one or other reader. These changes were minor in all cases. There was no evidence in any subject of pleural plaques or of calcification. The mean (SD) age of this group with pleural disease was 47 (11) years, with a mean employment of 10 (7) job years. One subject was known to have a past history of tuberculosis. There was no history of exposure to asbestos. In most cases the pleural changes could have been the result of an inflammatory process, such as pneumonia.

There was no significant difference between the smoking habits of the six occupational groups $\left(\chi^{2}=6.06, \mathrm{df}=10, \mathrm{p}>0.8\right)$ but analysis of variance showed that the remaining variables-age, radiographic score, years in job, and adjusted $\mathrm{FEV}_{1}$ and FVCdiffered significantly. Further analysis was restricted to the 208 workers with respiratory measurements. These subjects were divided

Table 2 Age, smoking habit, length of employment, adjusted FEV , adjusted FVC, and radiographic score of workers in each occupational group

\begin{tabular}{|c|c|c|c|c|c|c|c|c|c|}
\hline \multirow[b]{2}{*}{ Occupation } & \multirow[b]{2}{*}{$n$} & \multirow[b]{2}{*}{$\begin{array}{l}\text { Mean (SD) } \\
\text { age (years) }\end{array}$} & \multicolumn{3}{|c|}{ Smoking habit (\%) } & \multirow[b]{2}{*}{$\begin{array}{l}\text { Mean }(S D) \\
\text { job years }\end{array}$} & \multicolumn{2}{|c|}{ Adjusted mean (l) } & \multirow[b]{2}{*}{$\begin{array}{l}\text { Radiographic } \\
\text { score }\end{array}$} \\
\hline & & & $\begin{array}{l}\text { Current } \\
\text { smoker }\end{array}$ & $\begin{array}{l}\text { Ex- } \\
\text { smoker }\end{array}$ & $\begin{array}{l}\text { Never } \\
\text { smoker }\end{array}$ & & $F E V_{1}$ & $F V C$ & \\
\hline Packing & 39 & $46(11)$ & 59 & 5 & 36 & $12(6)$ & $3 \cdot 14$ & $4 \cdot 08$ & 0.78 \\
\hline Plant & 74 & $37(10)$ & 58 & 12 & 30 & $9(6)$ & $3 \cdot 57$ & $4 \cdot 52$ & 0.93 \\
\hline Maintenance & 23 & $45(11)$ & 74 & 4 & 22 & $13(5)$ & $3 \cdot 20$ & $4 \cdot 29$ & 0.85 \\
\hline Office & 22 & $36(9)$ & 54 & 14 & 32 & $9(6)$ & $3 \cdot 66$ & $4 \cdot 51$ & 0.76 \\
\hline Laboratory & 30 & $30(4)$ & 57 & 6 & 37 & $7(4)$ & $3 \cdot 74$ & $4 \cdot 61$ & $0 \cdot 84$ \\
\hline Mine & 20 & $40(11)$ & 70 & 10 & 20 & $9(8)$ & $3 \cdot 68$ & $4 \cdot 81$ & 0.97 \\
\hline $\begin{array}{l}\text { Vitalograph data } \\
\text { not available }\end{array}$ & 10 & $43(14)$ & 90 & 0 & 10 & $9(6)$ & & & \\
\hline
\end{tabular}

$\mathrm{FEV}_{1}$-forced expiratory volume in one second; FVC—forced vital capacity. 
Table 3 Agreement between observers 1 and 2 for the ILO scores for the profusion of small opacities ${ }^{2}$

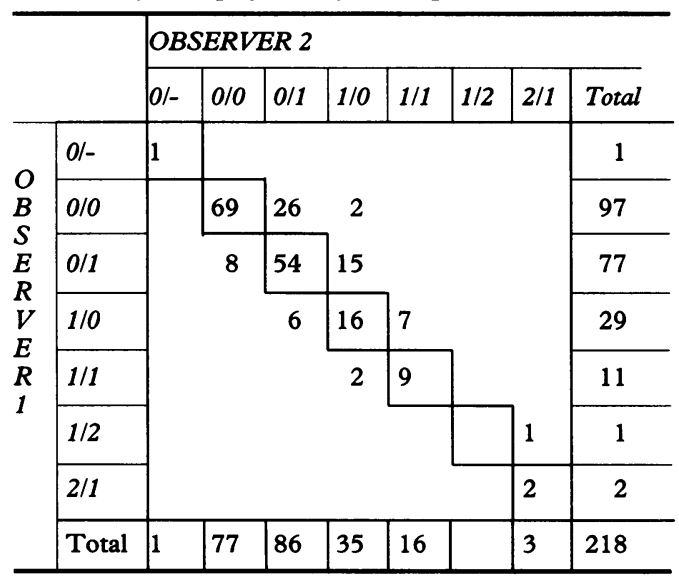

into those exposed to the dried sepiolite dust and those who either had not been exposed or had been exposed only to the moisture laden rock. Packaging, maintenance, and other plant workers were considered to have been exposed mainly to dry dust (group PMO, $n=136)$. Office, laboratory, and mine workers formed the other group (OLM, $n=72$ ). Table 4 shows the annual rate of change of the adjusted $\mathrm{FEV}_{1}$ in the two groups. On the basis of all 208 subjects, with no account taken of smoking habits, there was a significant decline with age in both groups, with a much steeper decline ( $p<$ 0.001 ) in the exposed group (PMO). The greater rapidity of decline could be seen from the values of $\mathrm{FEV}_{1}$ predicted by the two lines at ages 25 and 55. At younger ages there was if anything better lung function in group PMO, due partly to the "healthy worker effect" and to the fact that all eight women were in group OLM. At older ages, despite the sex difference and the possibility that more severely affected workers would change from group PMO, this group had considerably poorer $\mathrm{FEV}_{1}$. Table 4 also shows that the pattern remained similar when attention was restricted to lifelong non-smokers and to current smokers separately; the numbers of exsmokers were too small for meaningful estimation of the rate of deterioration with age. The difference in slopes between current smokers and those who had never smoked, with exposure controlled for, was in the expected direction but was relatively small and did not reach significance. A generally similar pattern applies to adjusted FVC (table 4), though here there was little evidence of

Table 4 Rates of change of adjusted forced expiratory volume in one second (FEV) and adjusted forced vital capacity (FVC) per year of age, for groups PMO (packaging, maintenance, and other) and OLM (office, laboratory, and mine)

\begin{tabular}{|c|c|c|c|c|c|c|c|c|c|}
\hline \multirow[b]{2}{*}{ Group } & \multirow[b]{2}{*}{$n$} & \multicolumn{2}{|c|}{$F E V_{1}$ change (l)/year } & \multicolumn{2}{|c|}{$\begin{array}{l}\text { Fitted values } \\
\text { at ages }\end{array}$} & \multicolumn{2}{|c|}{ FVC change (l)/year } & \multicolumn{2}{|c|}{$\begin{array}{l}\text { Fitted values } \\
\text { at ages }\end{array}$} \\
\hline & & Mean (SE) & $p$ & 25 & 55 & Mean (SE) & $p$ & 25 & 55 \\
\hline \multicolumn{10}{|c|}{$\begin{array}{l}\text { All (smoking } \\
\text { disregarded) }\end{array}$} \\
\hline PMO & 136 & $-0.046(0.004)$ & $<0.001$ & $4 \cdot 13$ & $2 \cdot 74$ & $-0.047(0.005)$ & $<0.001$ & $5 \cdot 11$ & 3.71 \\
\hline OLM & 72 & $-0.020(0.006)$ & $<0.01$ & $3 \cdot 89$ & $3 \cdot 29$ & $-0.009(0.008)$ & & $4 \cdot 72$ & $4 \cdot 45$ \\
\hline Differe & & $-0.026(0.007)$ & $<0.001$ & & & $-0.038(0.009)$ & $<0.001$ & & \\
\hline \multicolumn{10}{|c|}{$\begin{array}{l}\text { Lifelong } \\
\quad \text { non-smokers }\end{array}$} \\
\hline PMO & 41 & $-0.038(0.007)$ & $<0.001$ & 3.97 & $2 \cdot 83$ & $-0.040(0.007)$ & $<0.001$ & 4.99 & 3.79 \\
\hline OLM & 22 & $-0.009(0.008)$ & NS & $3 \cdot 84$ & $3 \cdot 56$ & $-0.005(0.014)$ & NS & $4 \cdot 76$ & $4 \cdot 62$ \\
\hline Differe & & $-0.029(0.010)$ & $<0.01$ & & & $-0.036(0.015)$ & $<0.05$ & & \\
\hline \multicolumn{10}{|l|}{$\begin{array}{l}\text { Current } \\
\text { smokers }\end{array}$} \\
\hline PMO & 83 & $-0.049(0.006)$ & $<0.001$ & $4 \cdot 14$ & $2 \cdot 68$ & $-0.050(0.007)$ & $<0.001$ & $5 \cdot 15$ & 3.66 \\
\hline OLM & 43 & $+0.016(0.008)$ & $<0.05$ & 3.81 & 3.32 & $+0.003(0.010)$ & NS & 4.55 & $4 \cdot 64$ \\
\hline \multicolumn{2}{|c|}{ Difference } & $-0.033(0.010)$ & $<0.01$ & & & $-0.053(0.012)$ & $<0.001$ & & \\
\hline
\end{tabular}

Table 5 Rates of change of radiographic score per year of age in groups PMO (packaging, maintenance, and other) and OLM (office, laboratory, and mine)

\begin{tabular}{|c|c|c|c|c|c|c|}
\hline \multirow[b]{2}{*}{ Group } & \multirow[b]{2}{*}{$n$} & \multicolumn{3}{|l|}{ Rate of change/year } & \multicolumn{2}{|c|}{ Fitted values at ages } \\
\hline & & mean $(S E)$ & $t$ & $p$ & 25 & 55 \\
\hline \multicolumn{7}{|c|}{ All (smoking disregarded) } \\
\hline $\begin{array}{l}\text { PMO } \\
\text { OLM }\end{array}$ & $\begin{array}{r}136 \\
72\end{array}$ & $\begin{array}{l}+0.0062(0.0023) \\
+0.0047(0.0034)\end{array}$ & $\begin{array}{l}+2 \cdot 70 \\
+1 \cdot 40\end{array}$ & $\begin{array}{l}<0.01 \\
\text { NS }\end{array}$ & $\begin{array}{l}0 \cdot 78 \\
0 \cdot 81\end{array}$ & $\begin{array}{l}0.96 \\
0.95\end{array}$ \\
\hline Difference & & $+0.0015(0.0041)$ & +0.37 & NS & & \\
\hline \multicolumn{7}{|c|}{ Lifelong non-smokers } \\
\hline $\begin{array}{l}\text { PMO } \\
\text { OLM }\end{array}$ & $\begin{array}{l}41 \\
22\end{array}$ & $\begin{array}{l}+0.0020(0.0033) \\
+0.0043(0.0036)\end{array}$ & $\begin{array}{l}+0 \cdot 60 \\
+1 \cdot 19\end{array}$ & $\begin{array}{l}\text { NS } \\
\text { NS }\end{array}$ & $\begin{array}{l}0.77 \\
0.73\end{array}$ & $\begin{array}{l}0.83 \\
0.86\end{array}$ \\
\hline Difference & & $-0.0023(0.0049)$ & -0.48 & NS & & \\
\hline \multicolumn{7}{|c|}{ Current smokers } \\
\hline $\begin{array}{l}\text { PMO } \\
\text { OLM }\end{array}$ & $\begin{array}{l}83 \\
43\end{array}$ & $\begin{array}{l}+0.0054(0.0030) \\
+0.0062(0.0052)\end{array}$ & $\begin{array}{l}+1 \cdot 75 \\
+1 \cdot 20\end{array}$ & $\begin{array}{l}\text { NS } \\
\text { NS }\end{array}$ & $\begin{array}{l}0.78 \\
0.85\end{array}$ & $\begin{array}{l}0.95 \\
1.04\end{array}$ \\
\hline Difference & & $-0.0008(0.0060)$ & $-0 \cdot 13$ & NS & & \\
\hline
\end{tabular}


Table 6 Concentrations of respirable dust, total dust particles, and fibres

\begin{tabular}{|c|c|c|c|c|c|}
\hline \multirow[b]{3}{*}{ Location } & \multirow[b]{3}{*}{$\begin{array}{l}\text { Types of } \\
\text { job }\end{array}$} & \multicolumn{4}{|c|}{ Airborme dust and fibre concentrations } \\
\hline & & \multirow[b]{2}{*}{$\begin{array}{l}\text { Respirable } \\
\text { dust }\left(m g / m^{3}\right)\end{array}$} & \multirow{2}{*}{$\begin{array}{l}\text { Total dust } \\
\text { particles } / \mathrm{ml} \\
\text { (length } \\
>1.0 \mu \mathrm{m} \text { ) }\end{array}$} & \multicolumn{2}{|c|}{ Fibres $/ \mathrm{ml}$} \\
\hline & & & & Total & $\begin{array}{l}\text { Length } \\
\geqslant 7 \mu \mathrm{m}\end{array}$ \\
\hline Bagging shed & $\mathbf{P}, \mathbf{M}$ & & & & \\
\hline \multicolumn{6}{|l|}{ Operative filling } \\
\hline $20 \mathrm{~kg}$ bags & & $9 \cdot 5$ & 158 & 15 & 2 \\
\hline $5 \mathrm{~kg}$ bags & & $11 \cdot 4$ & 260 & 104 & 2 \\
\hline Special products & $\mathrm{P}, \mathrm{M}$ & $2 \cdot 3$ & 35 & 6 & - \\
\hline Bagging classifying & $\mathbf{P}, \mathbf{M}$ & $18 \cdot 5$ & 159 & 43 & - \\
\hline Primary crusher & $\mathrm{O}, \mathrm{M}$ & - & 35 & 2 & - \\
\hline Transport area & $\mathrm{O}, \mathrm{M}$ & - & 15 & $0 \cdot 1$ & - \\
\hline
\end{tabular}

$\mathrm{P}$-packaging; $\mathrm{M}$-maintenance; $\mathrm{O}$-other plant worker.

decline with age in group OLM.

Similar analyses of the radiographic score (table 5) show a general deterioration with age but no clear differences between exposure or smoking groups. The gravimetric concentration of respirable dust and the number concentrations of the particles and of the fibres making up the total dust cloud are tabulated in table 6 . High concentrations, exceeding the UK threshold limit value for nuisance dusts, were found in the bagging department and also in the classifier shed. Elongated particles, however, constituted a relatively small proportion of the total dust. Operatives do not work continuously in the classifier shed and respirators are usually worn, but the bag filling operatives are exposed continuously. Because of his lower output the operative filling bags in the special products department has a significantly lower exposure. At the primary crusher the short term sample of total dust obtained indicated the maximum concentration to which the operator was exposed during the hopper loading period; his average daily exposure would be much lower. The sample obtained in the

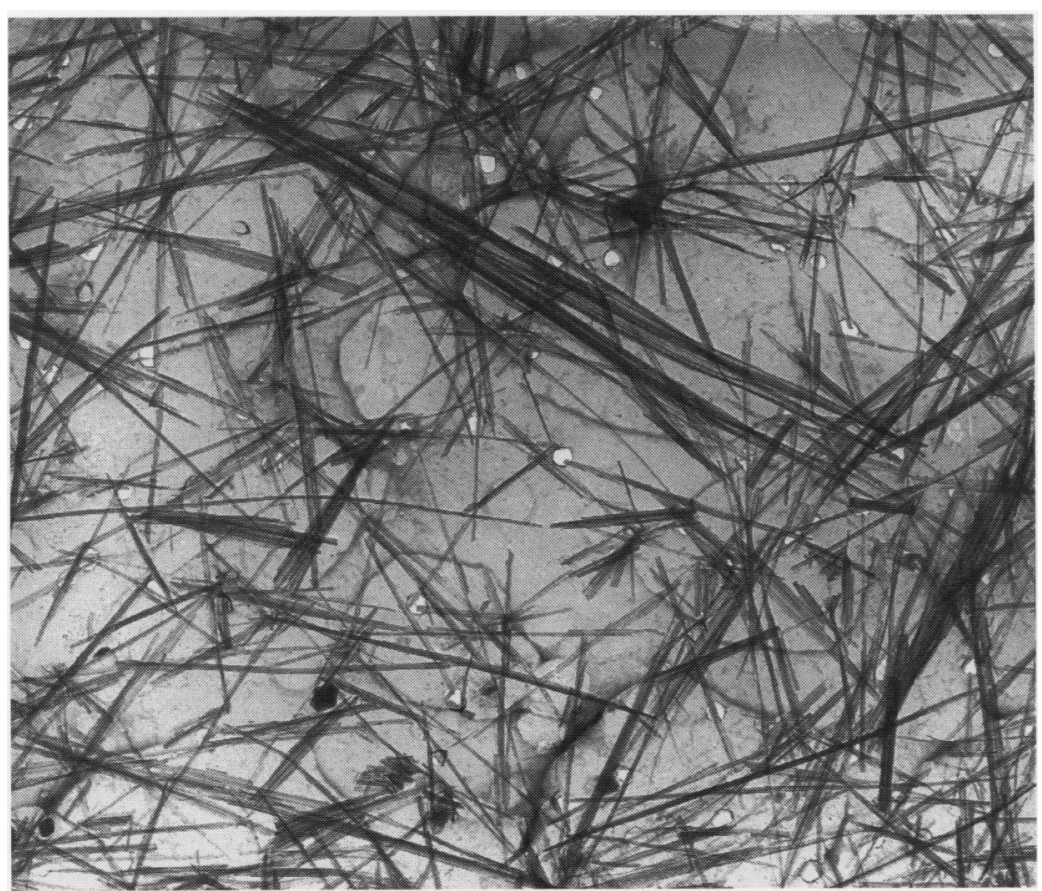

Electron micrograph of a commercial sample of sepiolite.
Table 7 Size distribution of airborne fibres

\begin{tabular}{|c|c|c|c|}
\hline \multicolumn{2}{|l|}{ Fibre length } & \multicolumn{2}{|c|}{ Fibre diameter } \\
\hline Range $(\mu m)$ & $\begin{array}{l}\text { Madrid } \\
\text { sepiolite (\%) }\end{array}$ & Range $(\mu m)$ & $\begin{array}{l}\text { Madrid } \\
\text { sepiolite (\%) }\end{array}$ \\
\hline$<1 \cdot 0$ & $6 \cdot 5$ & $<0 \cdot 1$ & $2 \cdot 8$ \\
\hline $1 \cdot 0-1 \cdot 9$ & $55 \cdot 1$ & $0.1-0.19$ & $60 \cdot 8$ \\
\hline $2 \cdot 0-2 \cdot 9$ & $26 \cdot 2$ & $0.2-0.29$ & $25 \cdot 2$ \\
\hline $3 \cdot 0-3.9$ & $8 \cdot 4$ & $0.3-0.39$ & $5 \cdot 6$ \\
\hline $4 \cdot 0-4 \cdot 9$ & $1 \cdot 0$ & $0.4-0.49$ & $3 \cdot 7$ \\
\hline $5 \cdot 0-6 \cdot 9$ & 0.9 & $0.5-0.59$ & - \\
\hline $7 \cdot 0-9 \cdot 9$ & - & $0.6-0.69$ & - \\
\hline$\geqslant 10.0$ & $1 \cdot 9$ & $0 \cdot 7+$ & $1 \cdot 9$ \\
\hline
\end{tabular}

transport area was again a sample representing a short period, indicating the concentration of dust in the air on a day when there was little or no wind.

Fibres - that is, particles having length: diameter ratios equal to or greater than 3 formed a proportion of the dust, but most were shorter than $7 \mu \mathrm{m}$. The longer fibres were elongated aggregates of interdigitated short fibres. Table 7 shows the size distribution of airborne fibres from Madrid sepiolite.

The experiment to assess the possibility of release of fibres under wet and dispersive conditions showed that the more gentle dispersion treatment of shaking the dust in water produced very few single fibres. The dust was in rounded aggregates or elongated bundles. Ultrasonic dispersion produced $115 \times 10^{6}$ fibres $/ \mu \mathrm{g}$, whereas shaking in water produced $0.4 \times 10^{6}$ fibres $/ \mu \mathrm{g}$. Wetting granules of sepiolite and lightly crushing them and then shaking them in water produced elongated fibrous bundles up to $8 \mu \mathrm{m}$ long; only occasional short single fibres were seen. Appreciable breakdown into fibrils required ultrasonic dispersion treatment.

\section{Discussion}

The results of a cross sectional study such as this, on the only available group of workers, must be interpreted with care; but fortunately the population has had a reasonable length of exposure-20 workers having been at this plant for 20 or more years.

On the basis of our analysis there is little reason to suspect any harmful effects in terms of chest radiographic appearances from inhalation of sepiolite. The major finding of this study is that lung function deteriorates more rapidly in those who have had more exposure to dust. The usually accepted normal annual decline in $\mathrm{FEV}_{1}$ and FVC is $0.03 / 1 .^{6}$ More recently Sherrill et al, ${ }^{7}$ using non-parametric regression techniques, have estimated that adjusted $\mathrm{FEV}_{1}$ deteriorated at a rate of 0.0461 /year in symptomless male smokers aged 48 years and over. Our finding of a deterioration of 0.0491 /year in male smokers in the group exposed to dry dust (average age 41 years) should be seen in this context. This effect on lung function is probably a reflection of previous dust concentrations rather than present ones. The 
cumulative dust exposure of this population is unlikely to be exceeded by future workers as measures have been taken to reduce dust concentrations.

There was no evidence of pleural plaque and no reported mesothelioma. On balance, mesothelioma seems unlikely to occur as there is no evidence of pleural disease related to length of exposure. The long latent period for mesothelioma that follows asbestos exposure, however, is well known. Previous unpublished radiological surveillances in 1979 and 1983 of a selected sample of workers from the same work force found no evidence of malignant disease. Burilkov and Michailova ${ }^{8}$ found endemic pleural plaque in a tobacco growing area of Bulgaria, where soil samples contained anthophyllite and tremolite as well as sepiolite. Baris $e t a l^{9}$ conducted a radiological survey of $70 \%$ of the population of four Turkish villages where meerschaum, a solid form of sepiolite, is carved to make tourist souvenirs. Miniature chest radiographs failed to show any evidence of pleural disease but were not of sufficient quality for estimating parenchymal damage. One pleural mesothelioma was found, in a man who had also been exposed to tremolite. Standard radiographs were obtained from a further 63 meerschaum trimmers, of whom 10 had evidence of parenchymal disease. In all cases there was another valid explanation, making it impossible to implicate meerschaum as the cause for these changes.

Fibre length is an important determinant of the biological effect of all fibrous materials. As yet there is no evidence of a safe threshold, but probably most damage is produced by fibres longer than $8 \mu \mathrm{m}$. Durability of the fibres is also considered important and a reproducible in vitro test of this is still sought.

The sepiolite plant we investigated is the largest in the world but difficulties arise because the subgroups of workers are small and no lung function and radiological data on the normal Spanish population are available for comparison.

This study has shown that extensive exposure results in a lowering of lung function but that this is not associated with any radiological change. Domestic users of, for example, cat litter would have a lifetime exposure roughly equal to that received in 20 days spent in the plant and are therefore unlikely to suffer lung damage.

We are grateful to the late Professor PD Oldham for statistical advice and the staff of Tolsa SA, Madrid, for their wholehearted cooperation with this study.

1 Wagner JC, Griffiths DM, Munday DE. Experimental studies with palygorskite dusts. $B r \mathcal{F}$ Ind $M e d$ 1987;44: $749-63$.

2 International Labour Office. Guidelines for the use of ILO international classification of radiographs of pneumoconioses. Geneva: ILO, 1980. (Occupational safety and health series No. 22.)

3 Oldham PD. Numerical scoring of radiological simple pneumoconiosis. In: Walton WH, ed. Inhaled particles III. Old Woking, Surrey: Unwin, 1971: 621-32.

4 Cole TJ. Linear and proportional regression models in the prediction of ventilatory function. Fournal of the Royal Statistical Society, series A 1975;138:297-338.

5 Griffiths DM, Hill RJ. The effects of dispersion on fibrous clays in vitro and in vivo. Ann Occup Hyg 1983: 27:405-14.

6 Cotes JE. Lung function: assessment and application in medicine, 4th ed. Oxford: Blackwell, 1979;329-87.

7 Sherrill DL, Lebowitz MD, Knudson RJ, Burrows B. Smoking and symptom effects on the curves of lung function growth and decline. Am Rev Respir Dis 1991; 144:17-22.

8 Burilkov T, Michailova L. Asbestos content of the soil and endemic pleural asbestosis. Environ Res 1970;2:443-51.

9 Baris YI, Sahin AA, Erkan ML. Clinical and radiological study in sepiolite workers. Arch Environ Health 1980;35: 343-6. 